\title{
Changes To The Intermediate Accounting Course Sequence
}

Lesley H. Davidson, Austin Peay State University, USA

William H. Francisco, Austin Peay State University, USA

\begin{abstract}
There is an ever-growing amount of information that must be covered in Intermediate Accounting courses. Due to recent accounting standards and the implementation of IFRS this trend is likely to continue. This report incorporates the results of a recent survey to examine the trend of spending more course time to cover this additional material. Two-hundred universities throughout the United States were surveyed during the last two months of 2008 and the first two months of 2009 in order to gather the data used in this report. Eight questions were asked of the respondents ranging from accreditation of the program to the faculty attitudes and perceptions. The results indicate that forty percent of the universities surveyed required more than the standard two (3 credit hour) courses in Intermediate Accounting. Some of the universities that have made changes in their program now offer a three course Intermediate Accounting sequence while others are requiring two courses of four credit hours rather than the traditional three hours. There does not seem to be a direct correlation between AACSB accredited programs verses non-accredited. Both types of institutions did not statically differ in their course delivery methods. Several universities indicated that even though a change had not been made, it was being considered.
\end{abstract}

Keywords: Intermediate Accounting, Accounting Education

\section{INTRODUCTION}

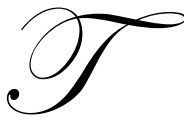

he body of knowledge in Accounting has been expanding for many years. Recently this expansion has been accelerated by two main factors. The first factor is the increasing scrutiny of the accounting profession as a result of the financial failure of many large corporations during the past decade. The second is the upcoming introduction of International Financial Reporting Standards (IFRS). Accounting Professors have seen an ever growing amount of information being "crammed" into the standard Intermediate Accounting two course sequence which is typically used on most campuses in the United States. This manuscript explores the concept of altering the typical Intermediate Accounting sequence for the benefit of student understanding and comprehension of an ever growing body of knowledge.

The authors examined the Accounting programs of a sampling of universities throughout the United States to see what changes were currently being implemented by various colleges to address this topic. A survey instrument was e-mailed to a randomly selected sample of universities to assess which programs had changed their pedagogy to meet the students' needs for the increased information necessary for their academic achievement. Additional information was requested on what program changes were made by the sampled universities and what difficulties were experienced during the transition period.

\section{RATIONAL FOR THIS RESEARCH}

The topic of recreating the course structure for financial accounting has not been readily addressed in past research. While most universities realize that the body of knowledge is expanding at a rapid rate, many accounting programs have not directly addressed the issue. An examination of four leading textbooks currently being published shows how the scope of material had increased. 
A review of the largest selling intermediate textbooks is quite revealing. On average the books by lead authors Spiceland, Kieso, Nikolai, and Stice have increased an average of $7.2 \%$ from their last edition. Additionally many of the comments listed on the various publishers' websites attribute much of the increase to the incorporation of IFRS. Specifically the Stice textbook website states,

"As the business workplace becomes more global, students need to understand how accounting practices may differ depending on the countries involved in a transaction. Nearly every chapter includes updated coverage of this nature and relevant sections that discuss the international standards are flagged in the margin with an IASB icon. A new chapter (Chapter 22) offers coverage of International Financial Reporting Standards to reflect the changing nature of the financial reporting environment." (Cengage, 2009)

Additionally the website for the Nikolai book states,

"New convergence overview: ... details the process that the FASB and IASB are using to converge U.S. GAAP and international GAAP. Chapter 2 summarizes the tentative Joint FASB and IASB Conceptual Framework... In the eleventh edition, for each of these chapters the text includes at least one IFRS versus U.S. discussion box that contains an updated and expanded summary of the differences between the two. New IFRS homework: The eleventh edition includes new international questions, as well as an international requirement to at least one exercise and one problem in each of chapters 4 through 23. The exercises and problems require students either to discuss how the solution would change under IFRS or to solve the assignment using IFRS. These requirements are based on the information in the IFRS versus U.S. GAAP discussion boxes." (Cengage, 2009)

In reviewing these changes it becomes obvious that examination of alternative course coverage options is a relevant discussion for any accounting program. The manner that is used to expand coverage and the methods to employ this expansion seems to be the only stumbling blocks.

\section{METHODOLOGY}

A survey of two- hundred universities was conducted via e-mail. The universities were randomly selected from the Hasselback Accounting Directory and the contact information for those institutions being surveyed was obtained. A list of the universities that responded to the survey can be found in Appendix A. The surveyors believed that there would be a greater response rate if the survey was conducted via e-mail rather than traditional mail or telephone. There was $24 \%$ response rate with a total of forty-seven universities responding.

The Accounting Department Chair or in some cases the Dean or Director was asked to respond to an eight question survey. A copy of the survey can be found in Appendix B. The surveyors asked questions relating to changing from a two course Intermediate Accounting sequence to a three course Intermediate Accounting sequence. Data requested dealt with topics such as when the change was made, implementation time, and how the additional course was accommodated in terms of the overall program. Other questions related to the attitudes of the faculty concerning the change and how the success of the students is being measured. There was also an area for the respondent to voice comments or concerns.

After allowing adequate time for responses, the results of the survey data were then compiled and interpreted. The responses were analyzed to find any discernable trends that could be established in relation to the possible transition. Specific areas addressed were the number and types of institutions who had made or were in their process of making curriculum changes to their Intermediate Accounting courses and their AACSB accreditation status. Additionally, the possible problems such as faculty attitudes and funding problems encountered in making the transitions were considered. Finally the methodology being used to implement the change was examined in an effort to see if the changes had received their desired results.

\section{RESULTS}

Sixty percent of the universities responding to the survey indicated that they are still using a two course Intermediate Accounting sequence with each course being three credit hours and have no plan to change. Twenty 
percent of respondents indicated that they had made the change to a three course sequence. The remaining $20 \%$ are in the process of making the change or have made another change such as changing the courses from 3 credit hours to 4 credit hours.

The data did not demonstrate a conclusive linkage between a college's accreditation status and a change in teaching pedagogy. The percentage of AACSB accredited institutions making changes was not substantially different that those institutions that were not accredited. For the universities that had made changes, only $47 \%$ of them were AACSB accredited in Accounting. It was concluded based on the responses given that there was no direct correlation between accreditation and the number of courses offered in the Intermediate Accounting sequence.

One of the survey questions inquired as to the reason that the change was made. The responses were centered on improving student learning and allowing for a more in-depth coverage of certain topics. Several universities also indicated that the new International Financial Reporting Standards will need to be covered once they are finalized, and will likely create a need for more class time.

The surveyors found that even though some of the universities were not offering a three course sequence in Intermediate Accounting, they had made other relevant changes such as pushing some material that is usually covered in Intermediate to an Advanced Accounting course or a Master's level course.

\section{CONCLUSION}

There was wide spread acceptance that changing the curriculum was a proper move by institutions who had changed their Intermediate Accounting structure. None of the schools surveyed indicated that they were considering going back and reducing their financial accounting coverage. There was also general acceptance among most respondents that something needed to be done to give students an opportunity to cover the increasing amount of information. A number of universities indicated that they were currently reviewing the matter. Even among schools that were not currently considering changing their Intermediate Accounting coverage, none of the respondents stated that they believed a change would have a negative effect on their program. Some of the main hurdles that had to be overcome were largely jurisdictional problems. Items such as reducing the number of elective choices for students and mandated limits on the maximum hours required for graduation provided stumbling blocks. Additionally it may be inferred that some faculty outside of the financial accounting area felt threatened that their classes would be cancelled or degraded to elective status.

In conclusion it may be stated that many institutions, once they have examined the pedagogy, will see a need for change. The body of knowledge is expanding so rapidly that to not adjust the curriculum will leave students at a competitive disadvantage on the CPA exam and in the workplace.

\section{AUTHOR INFORMATION}

Lesley H. Davidson is an Instructor of Accounting at Austin Peay State University in Clarksville, TN. She obtained her BBA from Austin Peay and her Masters of Accountancy from Belmont University in Nashville, TN. Mrs. Davidson teaches a variety of accounting courses including Financial and Managerial Accounting, Computer Applications in Accounting, and Forensic Accounting.

Bill Francisco CPA/CMA is an assistant professor of accounting at Austin Peay State University. He has written numerous articles on educational topics in business.

\section{REFERENCES}

1. American Institute of Certified Public Accountants, 2009, www.aicpa.org

2. Cengage Learning, 2009, www.cengage.com 


\section{APPENDIX A}

\section{Alphabetical Listing of Universities Participating in Survey}

Appalachian State University

Arkansas State University

Babson College

Brigham Young University

Edgewood College

Florida Gulf Coast University

Florida International University

Frostburg State University

George Mason University

Idaho State University

Lenoir-Rhyne University

Maryville University

Minnesota State University- Mankato

Mississippi State University-Meridian

Mount St. Mary's University

Michigan State University

Niagara University

Northeastern State University

Penn State- Harrisburg

Pepperdine University

Purdue University

Queens University of Charlotte

Rhode Island College

Saginaw Valley State University

SUNY-Geneseo

Texas State University

The College of New Jersey

Trinity University

University of Alabama

University of Arkansas

University of California- Irvine

University of Denver

University of Florida

University of Memphis

University of Minnesota

University of Nebraska- Omaha

University of North Florida

University of Northern Iowa

University of Tennessee- Knoxville

University of Texas- El Paso

University of Virginia

University of North Texas

University of South Dakota

Valparaiso University

Virginia Commonwealth University

Washburn University

WCPA 


\section{APPENDIX B}

\section{Intermediate Accounting Survey}

1. School name:

2. Is this university AACSB accredited (yes or no) Business accounting

3. Reasons for change: Why did you change from 2 courses to 3 ?

4. Time implemented: How long have you been doing the 3 course sequence?

5. How did the university accommodate the extra course?
a. $\quad$ Add an extra course?
b. Drop another course?
c. Limit electives?
d. Other? (describe)

6. Faculty Attitudes:
a. Initial faculty response?
b. Do they like it now?
c. Have they considered switching back?

7. How is the university measuring the success of the students?

8. Other comments or concerns? 
NOTES 